\title{
Treatment of pressure ulcers with larvae of Lucilia sericata
}

\author{
Erdal Polat, ${ }^{1}$ Zekayi Kutlubay, ${ }^{2}$ Serhat Sirekbasan, ${ }^{1}$ Hilal Gökalp, ${ }^{3}$ Ülkü Akarırmak ${ }^{3}$ \\ ${ }^{1}$ Department of Medical Microbiology, Cerrahpaşa Medical Faculty, İstanbul University, İstanbul, Turkey \\ ${ }^{2}$ Department of Dermatology, Cerrahpaşa Medical Faculty, İstanbul University, İstanbul, Turkey \\ ${ }^{3}$ Department of Dermatology, Koç University Medical Faculty, İstanbul, Turkey
}

Received: September 2016 Accepted: December 2016

\begin{abstract}
Objectives: This study aims to investigate the use of the Lucilia sericata larvae in patients with decubitus ulcers resistant to hyperbaric oxygen treatment, vacuum-assisted closure, surgical debridement, and other conventional therapies.

Patients and methods: A total of 36 patients (21 females, 15 males; mean age 63.7 years; range 16 to 90 years) who were admitted to our hospital for decubitus ulcers between February 2011 and July 2016 were included in our study. All patients had one or more lesions in the sacral region, trochanteric area, dorsal region, or on the heel of the foot. Nine patients had spinal cord injuries, six of them were injured during a car accident, and three of them had spinal cord injuries due to gunshot. One patient had concomitant lung cancer, one had heart failure, and two patients had a diagnosis of multiple sclerosis. Thirty three of 36 patients were admitted to the wound therapy unit within the department of emergency medicine, and three were admitted to the physical therapy and rehabilitation clinic. For each patient, Lucilia sericata maggots were applied on the lesions for 72 hours and, then, washed away. This procedure was repeated two times a week. Twenty nine patients (78.9\%) had four to six sessions and seven patients (21.1\%) had eight to 12 sessions.

Results: Twenty nine lesions (78.9\%) were Grade 2 and 3 and were completely healed after four to eight treatment sessions, while seven lesions (21.1\%) were completely cured at the end of 10 to 14 sessions. There was complete clearance of necrotic debris at the end of two sessions within the first week for 15 lesions, whereas 10 lesions (27.8\%) were cured after four sessions within two weeks, seven lesions (19.4\%) within five sessions after three weeks, and four lesions (11.1\%) were treated at the end of seven sessions for four weeks. All the necrotic crusts over the surface of the ulcers were cleaned and bad odor of the lesions disappeared.

Conclusion: Lucilia sericata larvae debridement is a rapid and effective treatment option for the management of chronic decubitus ulcers which are resistant to conventional therapies and other treatment modalities such as hyperbaric oxygen, vacuum-assisted closure, and surgical debridement.
\end{abstract}

Keywords: Decubitus ulcer; Lucilia sericata larvae; Maggot debridement therapy.

Unrelieved pressure is the main cause of decubitus ulcers which are usually seen in debilitated patients. The pressure between the external hard surface (the patient's seat or bed) and a bony protuberance can cause an ulcer in the area, if it exceeds the tissue blood pressure and the maximum duration the tissue can tolerate ischemia. ${ }^{[1]}$ The second most common reason is neurological disorders, while other causes include infection, diabetes, and advanced age. ${ }^{[1]}$ An important reason for pressure ulcer development is bacterial colonization as it increases collagenolytic activity and leads to tissue necrosis in such ulcers. The defense mechanisms of the body become inadequate in the areas with deficient blood supply, leading to easy proliferation of bacteria. The probable cause is a weakened immune system together with moisture and ischemia due to the disturbed blood supply. ${ }^{[1]}$ The most common locations of pressure ulcers are between the buttocks (sacrum), the bony protuberances in the sitting area (ischium) and the protuberances on the sides of the hip (trochanter). The occipital protuberance, the heel, and the lower side of the scapula are the other potential pressure ulcerative areas in bedridden patients. ${ }^{[1]}$

The treatment of pressure ulcers is usually with hyperbaric oxygen treatment, vacuum-assisted closure

Corresponding author: Erdal Polat, MD. İstanbul Üniversitesi Cerrahpaşa Tıp Fakültesi Tibbi Mikrobiyoloji Anabilim Dalı, 34098 Cerrahpaşa, Fatih, İstanbul, Turkey. e-mail: erdalp@istanbul.edu.tr 
(VAC), surgical debridement, and classical methods. ${ }^{[2-4]}$ Larval debridement therapy (LDT) has also been used since 1990 in the United States (US), Israel, United Kingdom (UK), Germany, Sweden, Switzerland, Ukraine, and Thailand for venous stasis ulcers, temporal mastoiditis, Fournier gangrene, necrotic tumor masses, and other soft tissue injuries. ${ }^{[5,6]}$

Larval excretions have been found to contain at least two antibacterial substances with one similar to a hydrophobic peptide of 3-10 $\mathrm{kDa}$ and the other a hydrophilic substance of $1 \mathrm{kDa}$. In 2007, Huberman et al. ${ }^{[7]}$ reported that Lucilia sericata (L. sericata) larval excretion with molecular weights of 138,152 , and $194 \mathrm{kDa}$ showed antibacterial activity against Grampositive (methicillin-sensitive Staphylococcus aureus [MSSA], methicillin-resistant S. aureus [MRSA]) and Gram-negative (Pseudomonas aeruginosa, Serratia marcescens, Escherichia coli, and Klebsiella pneumoniae) microorganisms. Larvae of the L. sericata fly species only attack dead tissue and help clean wounds. ${ }^{[7-11]}$ The larvae remove the dead tissue over the wound with the enzymes they secrete, disinfect the lesion by ingesting, killing, and halting the proliferation of the microorganisms, and stimulate the tissue for granulation development. ${ }^{[5,6]}$

In the present study, we aimed to use larvae of the L. sericata fly species to treat pressure ulcers which were resistant to hyperbaric oxygen treatment, VAC, surgical debridement, or classic treatment methods used for a long period.

\section{PATIENTS AND METHODS}

This retrospective study included a total of 36 patients (21 females, 15 males; mean age 63.7 years; range 16 to 90 years) who were admitted to our hospital for decubitus ulcers between February 2011 and July 2016 by simple random sampling. All patients had single or multiple pressure ulcers in various body areas, such as the sacrum, trochanter, back, and both heels. Demographic and clinical characteristics are shown in Table 1.

All of the patients previously underwent VAC; however, none of them benefited. In these patients, abundance of necrotic tissues and the need for debridement caused the failure and insufficiency of VAC therapy.

In our study, we administered treatment with Stage I larvae of the L. sericata fly species to the wounds of 33 patients presenting to the Emergency Medicine Department Wound Treatment Unit and three patients to the Physical Medicine and Rehabilitation Department of our hospital. The number of larvae directly placed on the wound was eight to 10 per $1 \mathrm{~cm}^{2}$ area for superficial wounds and more for deep wounds. The larvae were covered with sterile gauze and the patients were recommended to change the gauze often to dry out the wound site. The larvae were removed after being kept on the wound for 48 to 72 hours. The larva treatment was administered two times within the first week, followed by once a week, once every two weeks, and once a month as the treatment progressed, and according to the state of the necrotic tissue. The procedure was continued, until the necrotic tissue on the wound was fully removed and the bad odor disappeared. Larva treatment was continued, if the wound did not close during follow-up..$^{[10,11,12]}$ There were four to eight applications for 29 wounds (78.9\%) and 10 to 14 for seven wounds (21.1\%).

The approval for the study was granted by the Ethics Committee of Istanbul University, Cerrahpasa Medical Faculty with the ID number of 14620/2005. A written informed consent was obtained from each patient. The study was conducted in accordance with the principles of the Declaration of Helsinki.

\section{Statistical analysis}

Statistical analysis of the study results was performed with the IBM SPSS version 21.0

Table 1. Demographic and clinical characteristics of patients

\begin{tabular}{|c|c|c|c|c|c|c|c|c|c|c|}
\hline \multirow[b]{3}{*}{ Cause of the pressure ulcers } & \multicolumn{4}{|c|}{ Patients } & \multicolumn{6}{|c|}{ Location of the pressure ulcers } \\
\hline & \multirow[b]{2}{*}{ Age (year) } & \multirow[b]{2}{*}{$\mathrm{n}$} & \multicolumn{2}{|c|}{ Gender } & \multirow[b]{2}{*}{ Sacrum } & \multirow[b]{2}{*}{ Trochanter } & \multirow[b]{2}{*}{ Sacrum and trochanter } & \multirow[b]{2}{*}{ Ischium } & \multirow[b]{2}{*}{ Both heels } & \multirow[b]{2}{*}{ Total } \\
\hline & & & Female & Male & & & & & & \\
\hline Old and bedridden & $>75$ & 14 & 3 & 11 & 3 & 3 & 6 & 1 & 1 & 14 \\
\hline Paralyzed & $36-90$ & 9 & 3 & 6 & 5 & 2 & - & 2 & - & 9 \\
\hline Car accident & $16-90$ & 6 & 4 & 2 & 6 & - & - & - & - & 6 \\
\hline Spinal cord injury due to gunshot & $16-73$ & 3 & 2 & 1 & 2 & - & - & 1 & - & 3 \\
\hline Lung cancer & 53 & 1 & - & 1 & 1 & - & - & - & - & 1 \\
\hline Heart failure & 76 & 1 & 1 & - & 1 & - & - & - & - & 1 \\
\hline Multiple sclerosis & 59.61 & 2 & 2 & - & 2 & 1 & 1 & 1 & - & 2 \\
\hline Total & & 36 & 15 & 21 & 20 & 4 & 7 & 5 & - & 36 \\
\hline
\end{tabular}



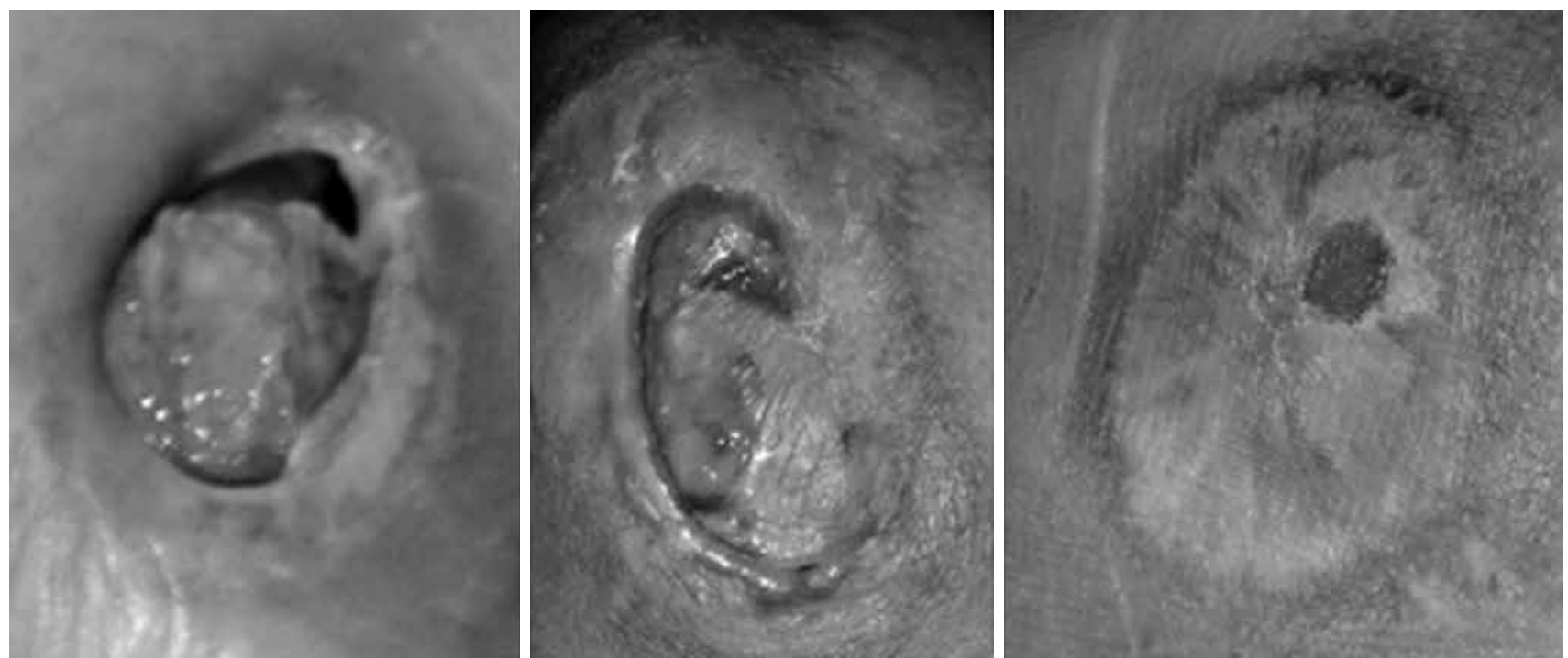

Figure 1. Treatment of left trochanteric pressure ulcer with larvae of Lucilia sericata in a multiple sclerosis patient.

(IBM Corp., Armong, NY, USA) program, and p-values under 0.05 were accepted as significant. Frequencies, percentages, mean and median values were calculated for descriptive statistics. Were analyzed by Chi-square that could predict the beneficial effects of LDT.

\section{RESULTS}

Of a total of 36 patients, 14 were over 75 years of age and bedridden, nine were aged between 36 to 90 years and paralyzed due to a stroke, six were aged between 16 to 90 years and were paralyzed due to spinal injury following a traffic accident, three were aged between 16 to 73 years and were paralyzed due to a firearm spinal injury, one was a 53-year-old bedridden patient due to lung cancer, another was a 76-year-old bedridden patient due to heart failure, and two were multiple sclerosis patients aged between 59 and 61 years.
The duration of pressure ulcers was 1.5 to 5 years in 33 patients, three months in one patient, six months in one patient, and eight months in one patient. The partial skin loss including the epidermis, dermis or both was present in some patients, while the wound had injured all skin layers with necrotic subcutaneous tissue in others. The pressure ulcers were classified as Grade 2 and 3.

A total of 29 of the pressure ulcers (80.6\%) which were resistant to long-term classical treatment fully healed within four to eight applications of LDT in a short duration (one to two months) (Figures 1, 2). Seven wounds (19.4\%) healed within three to four months with 10 to 14 LDT applications.

The necrotic tissues were fully removed and the bad odor of the lesion disappeared following LDT applied twice within the first week in 15 patients (41.7\%), four times within two weeks in 10 patients $(27.8 \%)$, five
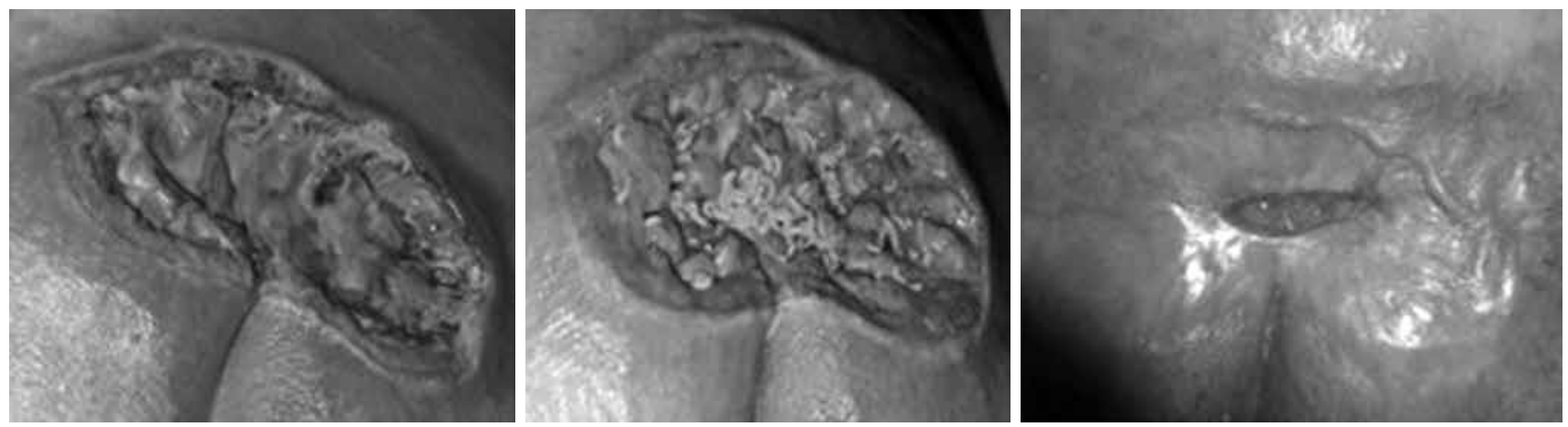

Figure 2. Treatment of sacral pressure ulcer with larvae of Lucilia sericata in a paralyzed patient. 
times within three weeks in seven patients (19.4\%), and seven times within four weeks in four patients (11.1\%).

\section{DISCUSSION}

Pressure ulcers have high morbidity and mortality rates and are difficult and expensive to treat. Lack of treatment may lead to infection and sepsis with fatal results. A pressure ulcer has been reported to develop in $15 \%$ of acute care patients and this rate increases up to $63 \%$, compared to the earlier reports. ${ }^{[13]}$ The mean cost of a pressure ulcer has been calculated as $\$ 48.000$ US in the US in 2006. The treatment cost of a pressure ulcer ranges from $\$ 20.900$ to $\$ 151.700$ US per case with an annual cost of 11 billion US. ${ }^{[14]}$ The annual cost in the UK is about $£ 1.4$ to 2.1 million. ${ }^{[15]}$ In addition, about 2.5 million patients suffer from pressure ulcers per year in Turkey and 60.000 of them die eventually. The cost of pressure ulcers has been estimated as $\$ 11.5$ billion US. ${ }^{[16]}$

Furthermore, pressure ulcers are a serious problem in bedridden patients and current treatment options include methods such as hyperbaric oxygen treatment, VAC, surgical debridement, and classical wound treatment. The initial step is debridement of the wound surface. All necrotic tissues should be removed from the wound surface, and infected foci should be drained..$^{[1-4]}$

The larvae enable rapid and effective debridement of the wounds, preserving the live tissues. The larvae avoid the light and, therefore, debride dead tissues without harming live tissues after easily accessing areas which cannot be reached by the surgeon's scalpel. Solutions such as povidone-iodine, hydrogen peroxide, acetic acid, sodium hypochlorite, and silver sulfadiazine should not be used for topical wound care following debridement. This is because these solutions damage tissue granulation and the newly growing tissues stimulated by the larval debridement. The ideal material to use following debridement is, thus, physiological saline.

Once the wound is cleaned with debridement, it is closed with primary closure, skin grafts, local skin flaps, muscle-skin flaps, fasciocutaneous flaps, and neurosensory flaps. However, it is impossible to guarantee new wounds would not develop after any kind of closure. There is no need to close the wounds, when LDT is used as they close spontaneously.

The expression of many genes and messenger ribonucleic acid (mRNAs) change at the early stage (on Day 4), intermediate stage (on Day 7), and final stage (on Day 10) with the effect of larval secretions. It results in restructuring of the extracellular matrix, cellular proliferation, cellular migration, angiogenesis, collagen modeling (destruction \& restructuring), and modification of the inflammatory process. ${ }^{[17,18]}$

Currently, the LDT has been applied by many centers in many countries across the world. There are many medical centers focusing on intractable and non-healing wounds, which use LDT. In previous studies, Maggot therapy was found to be more potent and useful in chronic pressure ulcers treatment than conventional treatment methods prescribed with rare side effects. In addition, LDT may directly stimulate cellular proliferation of the granulation tissue. ${ }^{[19,20]}$

In our study, we used LDT to treat pressure wounds which were previously exposed to long-term treatment with hyperbaric oxygen treatment, VAC, surgical debridement, and classical wound treatment which became deeper and larger over time. L. sericata larvae led to full wound closure in 29 patients $(80.6 \%)$ after four to eight applications within a short duration (one to two months), while such closure occurred within three to four months with 10 to 4 applications of LDT in seven patients (19.4\%).

Pressure ulcers can develop due to immobility in the long-term coma patients and those with multiple fractures where casts or traction is used. The patient suffers from involuntary contractions following spinal injuries due to local reflex activity development in the distal section in complete sections of the spinal cord. The wound region can, therefore, become easily contaminated with feces, urine or from the surrounding areas, and anaerobic infections may develop. These can lead to bad odor in the wound. The wounds of our patients had bad odor due to the colonization by aerobic bacteria or infections by anaerobic bacteria. The necrotic tissues were completely cleared and the bad odor disappeared following LDT application twice within the first week in 15 wounds (41.7\%), four times within two weeks in 10 wounds $(27.8 \%)$, five times within three weeks in seven wounds (19.4\%), and seven times within four weeks in four wounds (11.1\%). The larvae are able to stop the proliferation of the microorganisms and kill them with the anti-bacterial substances, proteolytic enzymes, phenyl acetic acid, and phenyl acetaldehyde they produce. ${ }^{[9]}$ The live larvae placed on the wound also ingest the microorganism, clearing necrotic tissues from the wound bed, and provide protection 
from infections. ${ }^{[7,8,11]}$ Thomas et al. ${ }^{[9]}$ demonstrated that larvae could be used in the treatment of various types of wound infected with antibiotic-resistant agents by treating five lesions consisting of three pressure ulcers, one pilonidal sinus, and one large abscess infected with MRSA.

The results of our study and others have shown that LDT can be successfully used in the treatment of wounds, irrespective of the underlying cause. Larvae treatment is much more rapid and inexpensive than traditional treatment and is, therefore, an alternative treatment with favorable costs. ${ }^{[21-23]}$ The larvae placed on the wound secrete many anti-bacterial and antiLeishmanial substances, while transitioning from Stage II to Stage III. The larvae disinfect the wound with the enzymes they produce and stimulate tissue granulation. ${ }^{[21]}$

In addition, the digestive and hemolymph excretions of the larvae stimulate epidermal growth factor (EGF) and, thus, fibroblast cells, leading to fibroblast tissue growth. ${ }^{[18]}$ Larval extracts and EGF have been shown to stimulate fibroplasia through different mechanisms and to have a synergistic effect. ${ }^{[24]}$ Larval secretions prevent damage by neutrophils and their products (i.e., proteolytic enzymes, and reactive oxygen intermediaries) to the wound surface during the healing process of chronic wounds. They inhibit the neutrophil chemotaxis effect of the $\mathrm{N}$-formylmethionine-leucine-phenylalanine (fMLP). They also decrease the expression of adhesion molecules CD11b and CD18 which are found on activated neutrophils and support neutrophil adhesion to endothelial cells. This inhibitory activation of larval secretions prevents tissue destruction which may develop due to neutrophils in chronic wounds and suppresses the proinflammatory response without disturbing the antimicrobial activities of neutrophils. Wound debridement accelerates in tissue that start to grow with the stimulation of tissue granulation. ${ }^{[17,18,24]}$

The most important limitation of our studies is that it has a retrospective design. Prospective comparative data is needed for the generalization of these results.

In conclusion, LDT application leads to a much more rapid improvement of wounds, compared to classical treatment modalities, thanks to these effects of larval secretion and the stimulatory actions of the live larvae placed on the wound. We believe that LDT can be used together with other treatments in any kind of open wound, irrespective of the underlying cause, and would contribute to the rapid improvement in the wound tissues.

\section{Declaration of conflicting interests}

The authors declared no conflicts of interest with respect to the authorship and/or publication of this article.

\section{Funding}

The authors received no financial support for the research and/or authorship of this article.

\section{REFERENCES}

1. Yücel A. Bası yaraları tanı ve tedavisi. In: Erdost ŞK, Çetinkale O, editörler. Yara Bakımı ve Tedavisi. İstanbul: İ.Ü. Cerrahpaşa Tıp Fak; 2008. s. 37-57.

2. Aktaş Ş. Hiperbarik oksijen tedavisi: Yara tedavisindeki yeri. In: Erdost ŞK, Çetinkale O, editörler. Yara Bakımı ve Tedavisi. İstanbul: İ.Ü. Cerrahpaşa Tip Fak; 2008. s. 199-206.

3. Aktaş Ş. Kronik yara tedavisinde vakum yardımlı kapama. In: Topalan M, Aktaş Ş, editörler. Güncel Yönleriyle Kronik Yara. İstanbul: İ.Ü. İstanbul Tip Fak; 2010. s. 194-207.

4. Erdoğan B. Yara bakım ürünleri. In: Topalan M, Aktaş Ş, editörler. Güncel Yönleriyle Kronik Yara. İstanbul: İ.Ü. İstanbul Tip Fak; 2010. s. 143-71.

5. Bonn D. Maggot therapy: an alternative for wound infection. Lancet 2000;356:1174.

6. Polat E. Larva Debridman Tedavisi (LDT). Güncel yönleriyle kronik yara. In: Topalan M, Aktaş Ş, editörler. İstanbul Tip Fakültesi Kronik Yara Konseyi. 1. bask1. İstanbul: Aygül Ofset Matbaacılık; 2010. s. 181-93.

7. Bolaban D. Lucilia sericata larvaları ve salgılarının metisiline dirençli Staphylococcus aureus (MRSA) ve metisiline duyarlı Staphylococcus aureus (MSSA) üzerine antibakteriyel etkilerinin in-vivo ve in-vitro koşullarda araştırılması. Master thesis, Istanbul Universty Health Sciences Institute; 2009.

8. Huberman L, Gollop N, Mumcuoglu KY, Block C, Galun R. Antibacterial properties of whole body extracts and haemolymph of Lucilia sericata maggots. J Wound Care 2007;16:123-7.

9. Thomas S, Andrews A, Jones M. The use of larval therapy in wound management. J Wound Care 1998;7:521-524.

10. Sherman RA. A new dressing design for use with maggot therapy. Plast Reconstr Surg 1997;100:451-6.

11. Mumcuoglu KY, Miller J, Mumcuoglu M, Friger M, Tarshis M. Destruction of bacteria in the digestive tract of the maggot of Lucilia sericata (Diptera: Calliphoridae). J Med Entomol 2001;38:161-6.

12. Polat E, Çakan H, İpek T. Larva debridman tedavisi. Türk Aile Hek Derg 2010;14:188-91.

13. Amlung SR, Miller WL, Bosley LM. The 1999 National Pressure Ulcer Prevalence Survey: a benchmarking approach. Adv Skin Wound Care 2001;14:297-301.

14. Available from: http://www.hcup-us.ahrq.gov/reports/ statbriefs/sb3.pdf. [Accessed date: September 27, 2016].

15. Bennett G, Dealey C, Posnett J. The cost of pressure ulcers in the UK. Age Ageing 2004;33:230-5.

16. Available from: http://turkuazstandart.org.tr/ dokuman/16/6-soruda-basi-yarasi. [Accessed date: September 27, 2016]. 
17. Polat E, Aksöz İ, Arkan H, Coşkunpınar E, Akbaş F, Onaran İ. Gene expression profiling of Lucilia sericata larvae extraction/secretion-treated skin wounds. Gene 2014;550:223-9.

18. Coskunpinar E, Arkan H, Dedeoglu BG, Aksoz I, Polat E, Araz T, et al. Determination of effective miRNAs in wound healing in an experimental Rat Model. Cell Mol Biol (Noisy-le-grand) 2015;61:89-96.

19. Sherman RA. Maggot versus conservative debridement therapy for the treatment of pressure ulcers. Wound Repair Regen 2002;10:208-14.

20. Brin YS, Mumcuoglu KY, Massarwe S, Wigelman M, Gross E, Nyska M. Chronic foot ulcer management using maggot debridement and topical negative pressure therapy. J Wound Care 2007;16:111-3.
21. Mumcuoglu KY, Ingber A, Gilead L, Stessman J, Friedmann $\mathrm{R}$, Schulman H, et al. Maggot therapy for the treatment of diabetic foot ulcers. Diabetes Care 1998;21:2030-1.

22. Polat E. Lucilia sericata'nın larvaları ile zor iyileşen yaraların tedavisi. XV. Ulusal Parazitoloji Kongresi (18-23 Kasım 2007, Kayseri ve Ürgüp) Kongre program ve bildiri özet kitabı konferans- II, 2007. s. 57-60.

23. Polat E, Çakan H, Çalışkan R, Kondakçı G.O, Darı S, İpek T. Lucilia sericata'nın larvalarının kronik yaralarda uygulanması. Türkiye Parazitoloji Dernegi Ulusal Parazitoloji Kongresi (1-7 Kasım 2009, Adana) Program ve özet kitabı 2009. s. 83-85.

24. Prete PE. Growth effects of Phaenicia sericata larval extracts on fibroblasts: mechanism for wound healing by maggot therapy. Life Sci 1997;60:505-10. 